\title{
The Dualism Impact in Coal Business in Muara Enim Regency (South Sumatra Province) in The Reformasi Era
}

\author{
Nanda Julian Utama ${ }^{1}$, Andy Suryadi ${ }^{2}$, Atno $^{3}$, Syaiful Amin ${ }^{4}$ \\ \{nanda.julian@mail.unnes.ac.id ${ }^{1}, \underline{\text { andy.suryadi@mail.unnes.ac.id }}^{2}, \underline{\text { atno.sejarah@mail.unnes.ac.id }^{3},}$ \\ syaiful.amin@mail.unnes.ac.id $\left.{ }^{4}\right\}$
}

${ }^{1,2,3,4}$ Department of History, Faculty of Social Science, Universitas Negeri Semarang, Indonesia

\begin{abstract}
This article discusses the situation of the coal mining business in Muara Enim Regency, South Sumatra. The main problem in this article is what are the dual opposite impacts from the existence of coal mines business in Muara Enim regency, South Sumatra in the Reformasi era (around 1998-2018). Muara Enim Regency is already famous for being one of the largest coal producers in Indonesia. The biggest company that does coal mining in Muara Enim is PT. Bukit Asam (PT.BA). But PT.BA is not the only party involved in the coal business in Muara Enim Regency. In the Reformasi era, there were many private companies engaged in the coal mining business, including the people of Muara Enim itself which also involved personally in this business (Tambang Rakyat). From the economics side, coal mining increases the income of those who involved in it, especially most people who previously were farmers turned into miners. But on the other hand, this business also has several negative impacts, especially those related to the environment and infrastructure in Muara Enim Regency itself. The dualism of the impact that results from this business is interesting to be discussed from a historical perspective. This article also supported by a variety of primary sources such as archives and newspapers throughout the days as referent materials, and other relevant sources.
\end{abstract}

Keywords: Mining, coal, business benefits, environmental damage, Muara Enim, South Sumatera

\section{Introduction}

kinds of products which became the target of foreign traders. Since then the territory of Indonesia which was previously known as the Nusantara has become the target of western countries to be controlled. Around the 15 th and 16th centuries, the region was famous for plantation commodities, especially spices. But in the development of the next century, the plantation commodities targeted from regions in the Nusantara increased with the emergence of coffee plantations in the early 19th century. Not only that this region was also rich in various kinds of crops in the form of mining goods which had begun to be explored since 18 century [1].

These mining goods later became the leading commodities that provided benefits to the Dutch Colonial Government and various foreign companies. One of the mines that opened in the late 19th century was coal mining. This commodity has a very important function as fuel for various engines, especially steam engines which have diverse benefits, one of which is as a power plant. Besides that, the coal content in Indonesia is indeed very large, until the $21 \mathrm{st}$ century, Indonesia has become one of the top 5 coal exporters in the world [2]. 
One of the coal-producing regions in Indonesia is Muara Enim. Muara Enim is one of the districts in South Sumatra Province. Coal exploration in this area has been carried out since the end of the 19th century. This indicates that coal mining in this region is quite old, but the coal content in this region is still large. Therefore coal is one of the leading commodities in this region in addition to plantations. But the benefits generated through the coal business also have negative impacts such as environmental damage and damage to road infrastructure.

The problem regarding the impact of this mining on the environment is indeed quite crucial. The participation of citizens in voicing their opinions regarding this issue is very necessary. But in the case of Muara Enim, most people only focus on protests relating to damage to road infrastructure, not to the urgency of environmental damage. Related to this, the form of protest is rarely carried out in general, not only in Muara Enim Regency but also in a wider and public scope such as Sumatra. Recorded since (New Order) Orde Baru period until Reformasi there were around 109 reports of protests or only around $22 \%$ of the total protests in Indonesia. Unlike the case in Java in general where there are quite a lot of protests filed by the population related to natural and environmental damage as a result of various things, there were around 284 reports or a total of $54 \%$ of the total cases with the same period[3].

The main problem examined in this study is the impact of what happened as a result of coal mining in the Muara Enim Regency around 1998-2018 or in Reformasi era. From the preliminary explanation above, there is an initial explanation regarding the dualism of the impact on coal mining in the Muara Enim Regency. On the one hand, this mining provides material benefits to the business people. But on the other hand, these economic benefits also harm several things, especially on the environmental conditions around contaminated mining. This is what needs to be understood from the dualism concept used in this study where there are two conditions as a result of a situation that is superior and inferior conditions that stand at the same time [4].

\section{Research Method}

To understand the context of events that occur, this study will use historical methods [5]. The historical research method has four steps that must be worked out in stages. The first step in this research is gathering resources. The position of historical sources is very important in the writing of history. This research deals a lot with media sources that are widely spread through the internet, especially online newspapers from the beginning of Reformasi Era in 1998 until 2018. Besides, this research is also complemented with various publications issued by official government institutions such as the Central Statistics Agency of Muara Enim Regency and other secondary sources. The second step in historical research is source criticism where the historical source that has been obtained is criticized for its validity to be the main source in research. The third step is to interpret the data, this is also quite crucial considering the ability and intellectuality of historians also tested in this stage. Sources that have been obtained must not only be interpreted in general but also must be aware that historical sources can also be trapped when they will be interpreted. From here the researcher must be able to avoid or at least minimize errors in interpretation [6]. Some of the online sources previously obtained came from unclear websites, even though the narratives delivered were so compelling to be quoted. The final step in this research is in the process of historiography or writing history which results are outlined in this paper. 


\section{Result and Discussion}

\subsection{Two Side Of coint: Between Economic Benefits And Environmental Damage In Coal Mining.}

Muara Enim Regency is one of the regions in South Sumatra Province. This area is roughly located in the central part of the province of South Sumatra and has an area of around $7,383.9 \mathrm{~km} 2$. The region's main potential consists of plantation commodities and mining products. In the plantation sector, there are rubber and oil palm plantations that are quite widely spread in this region. Whereas in the mining sector, the Muara Enim Regency area is not only a producer of coal concentrated in Tanjung Enim District, where PT.BA operates. This region also produces oil with a significant amount of production [7].

Mining is not a newly explored sector in the South Sumatra region. This province has long been known as one of the producers of natural resources, especially in the mining sector. If seen further, then mining in South Sumatra would have existed around the end of the 19th century. At that time the Dutch Colonial Government began to carry out various types of exploration on mining goods, especially coal, but the production itself had only begun in the early 20th century. transportation of mining products, especially coal, still uses barges that are towed by steam vessels of various sizes. It was only after the railway network was successfully built in Palembang in the 1920s, the process of transporting coal mining products was also carried out by train [8].

The opening of the first coal mining company in the Muara Enim area was carried out in 1915. But the company itself was only able to produce coal excavations about two years later, namely in 1917. The position of this coal company was quite important in its early 20th century were not many regions which is known to produce coal. So that the Muara Enim area could be said to be one of the important producers of coal in the Dutch East Indies defeating coal mining in Ombilin (West Sumatra) and Bengkalis (Riau) [9].

After Indonesia became an independent country, several foreign companies in Indonesia were then nationalized by the Indonesian government. In 1950 the coal company at Muara Enim was then nationalized to become a state company (BUMN). Then in 1981 the company changed its status to a limited liability company (PT) and changed its name to PT. Bukit Asam or popularly abbreviated as PT.BA. At that time in the management of coal mining, PT.BA still used the open pit system [10].

This company (PT. BA) is an important element in managing coal mines in Muara Enim. It can be said that this company is a major player considering its position as a state-owned company (BUMN). Therefore the production and coal mining concessions at Muara Enim are indeed dominated by this company. Besides PT.BA, there are a lot of players in the mining business, both from the private sector and mining which are carried out on a small scale. Especially after the Reformasi began to appear various private companies engaged in coal mining. Even on a small scale, the people are also involved in this mining labeled as a people's mine. Most of those who work in the profession as miners previously worked in other sectors, especially plantations. However, because people's mining are more promising in terms of the economy, many people eventually become involved in this kind of mining. 


\subsection{Two Side Of coint: Between Economic Benefits And Environmental Damage In Coal Mining.}

Coal mining in Muara Enim district has the effect of significant profits for these business actors. if we reflect on the production carried out by large companies such as PT.BA, then during the last 15 years in the reform era, the company's production has always increased. This is because the demand for coal also increased significantly. As is generally known, one of the functions of coal is as electricity-producing fuel, while electricity supply increases over time.

Table 1. PT.BA Coal Production from 2005-2018

\begin{tabular}{llll}
\hline Year & $\begin{array}{l}\text { Total } \\
\text { tons) }\end{array}$ & Production (in million \\
\hline 2005 & 7.3 & & \\
2010 & 11.8 & & \\
2015 & 18.6 & & \\
2018 & 25.5 & & \\
\hline
\end{tabular}

Coal production that is always increasing is certainly in line with the company's increasing profits. Of the last production amount, which was in 2018, it was found that the profits of this state-owned mining company reached Rp. 5.02 trillion. The amount of this profit exceeds the predetermined expectations. even the amount of profit earned in 2018 is greater than the previous year which incised a profit of Rp. 4.47 Trillion [11]. In this regard, coal mining is a sector that cannot be underestimated in Muara Enim Regency. In addition, when compared to the national scale, PT .BA also occupies a significant position by entering the top 10 coal mining companies in Indonesia.

Besides PT.BA, there are quite several private companies that also operate in the coal mining sector. These companies also benefit significantly from this mining. One indication is the increasing number of companies opening licenses or issuing mining permits from the government issued to these companies. It is rather difficult to access data about the production and total profits of a private company, but there is one private company that discloses a little production. The company was named PT. Manambang Muara Enim (MM-Energi), where the company started its mining business since 2010. Recorded in 2016, the total coal production produced by this company reached 1.2 million tons of coal [12].

These companies, both government and private, are not the only players in this business. The community as well, especially the people of Muara Enim Regency also participated in this business. Mining business carried out by the people or the community is often known as the "Tambang Rakyat". This type of mine is usually carried out individually or in small teams of several people, besides that in this type of mining, the traditional tools are still often used. The existence of this people's coal mine is regulated in the Minerba Act No. 4 of 2009[13]. There is no definite number regarding the number of community miners in Muara Enim, but the Muara Enim Regency Statistics Agency recorded the amount in 2007 and 2015. Where there were approximately 8,036 workers in 2007 and decreased to 7,171 workers in 2015. However, this is somewhat doubtful considering that there are more numbers in the field, where the number is pre-workers who have mining permits. Whereas the reality in the field also arises various types of community mining that do not have permits or which are often referred to as mining without permits (Pertambangan Tanpa Izin /PETI)[14]-[16]. 
Community income in this sector is also significant. Most of the community miners were previously farmers, but after changing professions to become miners their income increased more than the previous profession. Data obtained from BPS statistics in 2015 regarding the average income of coal miners is around Rp. 2.1 million. However, this amount is somewhat less when compared to the reality found from the results of observations on some people who work in mines who can have an income of more than Rp. 6 million per month [15], [17].

But what are the advantages of these business people is inversely proportional to the negative impacts generated by coal mining, especially those that affect the environment. It is no longer an issue if coal mining often impacts on environmental pollution, especially what happens in Muara Enim. Almost all of these miners from large and small scale are involved in existing environmental damage. But it needs to be seen that large companies such as PT.BA and PT. Manambang Muara Enim has a division division engaged in environmental restoration. Besides that, the big companies also have CSR funds, one of which is for the management of polluted environments [18], [19].

Even so, large companies are still considered to be also responsible for environmental damage as a result of this coal mining. But a more significant portion can be seen in mine management from several small private companies and various community mines in Muara Enim. Most of the mining that they do still does not comply with good environmental management rules. As a result, quite a lot of environmental damage was found in Muara Enim, one of which happened in the Kiahan River in Muara Enim which was contaminated with coal mine waste [20]. Besides coal mining also causes landslides around mining sites. One of them happened in the river Enim. It was found that several mines were suspected of being illegal mines that were carried out around the river and had an impact on landslides around the river if illegal mining continued there [21].

In addition, another impact of the existence of this mine is deteriorating air quality in the Muara Enim area. There are no parties responsible for this air damage, even though the air waste around the mining area is not very good to breathe especially for residents who are not involved in this business at all. One indication of poor air quality is the high number of people affected by respiratory diseases or ISPA in Muara Enim. According to records from the Central Bureau of Statistics of Muara Enim Regency. In 2015 ISPA was the most common disease in the Muara Enim community [15].

The impact of environmental damage is very dominant, but the problems regarding coal mining do not stop at environmental damage. Damage to public infrastructure such as highways is also addressed in coal mining. Coal distribution using trucks with overload capacity is considered to damage roads in Muara Enim Regency, even provincial roads and state roads in South Sumatra. This is often ignored by mining managers who argue that road damage is not their responsibility. Interestingly, the community was interested in launching a protest movement against road damage compared to protests due to environmental damage.

although protests still exist they are in minimal numbers. Those who dared to protest were only a few parties, especially some people who were concerned about the environment and environmental activists who understood about the polluted environmental conditions. But these small-scale protests are very easy to suppress with various solutions that do not favor the people. But in other phenomena something is interesting why protests about this are very minimal, one of them is because too many people are involved in this business either directly as miners or those who get other benefits because of this mining. It cannot be denied if the rise of coal mining provides positive energy on the economic wheel of the community in Muara Enim especially with the emergence of various new economic ventures such as transportation, lodging, culinary, and others. But back to the substance, the community should be able to 
understand that the parties directly involved in the mining business are naturally doing the restoration of the damaged environment because of the mining they are doing [22].

\section{Conclusion}

Coal mining has had a significant positive impact, especially in the economic sector in Muara Enim Regency. Many parties involved started from the "big players" to those who "individual players" benefited significantly from this mining. But apparently, coal mines also harm the destruction of the environment. Environmental damage caused by mining can be seen from many aspects such as river damage, landslides, and reduced air quality around the mining area. This is what raises the dualism of the impact on coal mining, as the two sides of a coin that have different images in each corner. Both are in the same situation and time. This study saw a lack of participation from the government and the community as the party that gave permission and oversaw the operation of the mine. Therefore one of the recommendations of this study is to increase the participation of the government and surrounding communities as supervisors of this business. The government must be able to select which ones are feasible and not feasible to be granted mining permits. Besides that, the government must also be firm and not be allowed to selectively punish those who are guilty of this mining sector. Besides that, the participation of the community must also be improved, especially if you see or feel that there is an error in environmental management due to this mining. This is done at least to reduce the adverse effects resulting from this mining without reducing the positive impact that has been generated.

\section{References}

[1] B. Vlekke, Nusantara: Sejarah Indonesia. Jakarta: Kepustakaan Populer Gramedia, 2008.

[2] www.cnbcindonesia.com, "Ini 10 Negara dengan Produksi Batu Bara Terbesar di Dunia," 2019.

[3] Nawiyanto, "Berjuang Menyelamatkan Lingkungan: Gerakan Lingkungan Di Jawa Masa Kemerdekaan 1950-2000," Paramita Hist. Stud. J., vol. 25, no. 1, pp. 51-72, 2015.

[4] A. Lincoln, Ekonomi Pembangunan, 5th ed. Yogyakarta: STIM YKPN, 2010.

[5] H. Sjamsudin, Metodologi Sejarah. Yogyakarta: Penerbit Ombak, 2007.

[6] M. Lohanda, Membaca Sumber Menulis Sejarah. Yogyakarta: Penerbit Ombak, 2011.

[7] P. K. M. Enim, "Tentang Muara Enim,” 2013. .

[8] N. J. Utama, "Pelayaran dan Perdagangan di Sungai-sungai Keresidenan Palembang 1900-1930," Universitas Indonesia, 2017.

[9] M. Zed, Kepialangan Politik dan Revolusi di Palembang 1900-1950. Jakarta: LP3ES, 2003.

[10] www.ptba.co.id, "Sejarah Perusahaan.” .

[11] Www.finance.detik.com, "Bukit Asam Kantongi Laba Rp. 5,02 T Sepanjang Tahun 2018," 11 Maret 2018.

[12] Www.mm-energi.com, "Sekilas Tentang Manambang Energi." .

[13] Undang-undang Republik Indonesia No. 4 Tahun 2009 Tentang Pertambangan Mineral dan Batubara. Indonesia: Lembaran Negara Republik Indonesia No. 4 Tahun 
2009, 2009.

[14] B. P. S. (BPS), Muara Enim Dalam Angka Tahun 2007. Muara Enim: Badan Pusat Statistik Kabupaten Muara Enim, 2008.

[15] B. P. S. (BPS), Muara Enim Dalam Angka Tahun 2015. Muara Enim: Badan Pusat Statistik Kabupaten Muara Enim, 2016.

[16] I. Zulkarnain, Konflik di Daerah Pertambangan, Menuju Penyusunan Konsep Solusi Awal Dengan Kasus Pada Pertambangan Emas dan Batubara. Jakarta: LIPI, 2004.

[17] R. Aditya Eko Saputra, I Gede Sugiyanta, "Pertambangan Batubara di Desa Tanjung Lalang, Kecamatan Tanjung Agung," J. Penelit. Geogr., vol. Volume 3, pp. 1-13, 2015.

[18] www.tribunnews.com, "Mereka Kaya Mendadak," 2011. .

[19] www.ptba.co.id, "Berita CSR dan Lingkungan.".

[20] Www., "Diduga Sungai Kiahan Muara Enim Tercemar, Dinas Lingkungan Hidup Sumsel : Bukan dari PTBA.".

[21] Www.kompas.com, "Rawan Longsor, Tambang Batu Bara Ilegal di Muara Enim Ditutup.”.

[22] W. Buli, S. Bakri, and I. G. Febryano, "Kelembagaan Pertambangan Batubara di Hutan Rakyat,” J. Sylva Lestari, vol. 6, no. 3, pp. 81-90, 2018. 